\title{
Molecular Phylogeny of the Indo-Australian Glyphodes and its Allied Genera (Insecta: Lepidoptera: Crambidae: Spilomelinae) Inferred from Mitochondrial COI and COII and Nuclear EF-1 $\alpha$ Gene Sequences
}

\author{
Hari Sutrisno ${ }^{1}$, Noriko Azuma ${ }^{2}$ and Seigo Higashi ${ }^{2}$ \\ ${ }^{1}$ Museum Zoologicum Bogoriense, Research Center for Biology-LIPI, \\ Jl. Raya Bogor-Jakarta Km 46, Cibinong, Bogor, Indonesia \\ E-mail: sutrisnohari@yahoo.com \\ ${ }^{2}$ Graduate School of Environmental Earth Science, Hokkaido University, \\ Sapporo, 060-0810 Japan
}

(Received 11 December 2004; Accepted 3 December 2005)

The phylogeny of Indo-Australian Glyphodes (15 species), Talanga (three species), Agrioglypta (four species), and two outgroup species, Ostrinia nubilalis Hübner, 1825 and Metallarcha aureodiscalis (Hampson, 1918), was inferred from nucleotide sequence variation in the mitochondrial COI (686 bp) and COII $(687 \mathrm{bp})$ genes and the nuclear EF-1 $\alpha(973 \mathrm{bp})$ gene. While the third codon positions in COI and EF- $1 \alpha$ were not saturated with substitutions, those in COII were saturated when sequences were compared between genera. MP analyses based on pooled data of COI, COII, and EF- $1 \alpha$ resulted in two MP trees. The strict consensus tree showed that Glyphodes, Talanga, and Agrioglypta were all not monophyletic. Another analysis based on pooled data of all molecular and morphological data resulted in a single tree, in which monophyly of the genus Glyphodes was barely supported (bootstrap value $<50 \%$ ). Glyphodes species were divided into the same three clades as in an earlier published, morphology-based tree, one of these clades (the socalled Group 3) being supported by a bootstrap value of $100 \%$. In all analyses the genus Agrioglypta was shown to be paraphyletic, since A. eurytusalis (Walker, 1859) fell within the genus Talanga.

Key Words: Insecta, Lepidoptera, Crambidae, Glyphodes, molecular phylogeny.

\section{Introduction}

Glyphodes Guenée, 1854 and its allied genera Dysallacta Lederer, 1863, Talanga Moore, 1885, and Agrioglypta Meyrick, 1932 are medium-sized moths (15-51 mm) belonging to the subfamily Spilomelinae (Common 1990; Shaffer et al. 1996). These genera are morphologically diverse and widespread in tropical regions, with some species penetrating into subtropical and warm-temperate areas (Common 1990; Robinson et al. 1994).

Although nothing is known of the biology of any species of Dysallacta, almost all species of the other mentioned genera are host-specific to latex-containing plants of the Moraceae and Apocynaceae (Kalshoven 1981; Common 1990; Robinson 
et al. 1994), which occasionally suffer serious damage from larval feeding. For example, larvae of $G$. caesalis Walker, 1866 attack many species of Moraceae, such as Artocarpus heterophyllus Lam (jackfruit), A. rigida Blume (monkey jak), and $A$. elastica Reinw, in Indonesia and Thailand (Kalshoven 1981; Kuroko and Lewvanich 1993), and T. tolumnialis (Walker, 1859) is a common pest of cultivated figs Ficus carica Linnaeus in Queensland and New South Wales, Australia (Common 1990).

In spite of their impact on agricultural crops, the four moth genera Glyphodes, Dysallacta, Talanga, and Agrioglypta are poorly defined. Current generic classifications of these moths are based on superficial similarities (Common 1990; Robinson et al. 1994) and are in need of taxonomic revision. Until now, few comprehensive efforts have been made to improve the taxonomy or phylogeny of these genera by testing the monophyly of each genus and the relationships among the genera. As the principal exception, Sutrisno (2002) performed a cladistic analysis of Australian Glyphodes and its allied genera, including 18 species of Glyphodes, two species of Dysallacta, three species of Talanga, and four species of Agrioglypta, based on 40 morphological characters. However, a purely morphological approach failed to demonstrate the monophyly of each genus, and the reliability of each grouping was cast in doubt by low bootstrap values. This indicates the need for a molecular-phylogenetic approach to resolve relationships within this group.

As reported by numerous authors (reviewed in Simon et al. 1994; Brower and DeSalle 1998; Caterino et al. 2000), mitochondrial genes are useful for estimating phylogeny because of relative technical ease in processing and their maternal inheritance, haploidy, and absence of recombination events and introns (Goto and Kimura 2001). Among the mitochondrial genes, COI and COII are considered to be useful for estimating the phylogeny of closely related species (Brower 1994; Sperling and Hickey 1994; Caterino and Sperling 1999; Goto et al. 2000; Blum et al. 2003); nevertheless, mitochondrial protein-coding genes generally evolve fast and saturate rapidly (Liu and Beckenbach 1992) and, therefore, are not appropriate as phylogenetic markers in certain cases. In contrast, nuclear genes are generally more conservative and may be useful for inferring the phylogeny of distantly related taxa. Among nuclear genes, EF- $1 \alpha$ is the one most favored for inferring the phylogeny at different taxonomic levels in the Lepidoptera (Cho et al. 1995; Friedlander et al. 1998; Caterino et al. 2001; Monteiro and Pierce 2001; Rubinoff and Sperling 2002). Our purposes in the present study were: (1) to examine the monophyly of Glyphodes, Agrioglypta, and Talanga, and (2) to test the phylogenetic hypothesis derived from the earlier morphological analysis by analyzing the DNA sequences of the COI, COII, and EF-1 $\alpha$ genes.

\section{Materials and Methods}

\section{Morphological phylogeny of Glyphodes and its allied genera}

Sutrisno (2002) constructed a strict consensus MP tree based on 40 morphological characters (Fig. 1) and obtained the following results: first, Glyphodes species formed three distinct clades, referred to as Groups 1, 2, and 3; second, all species of Agrioglypta and Talanga formed an additional clade, with Talanga monophyletic but Agrioglypta paraphyletic with respect to Talanga; third, Glyphodes was not 

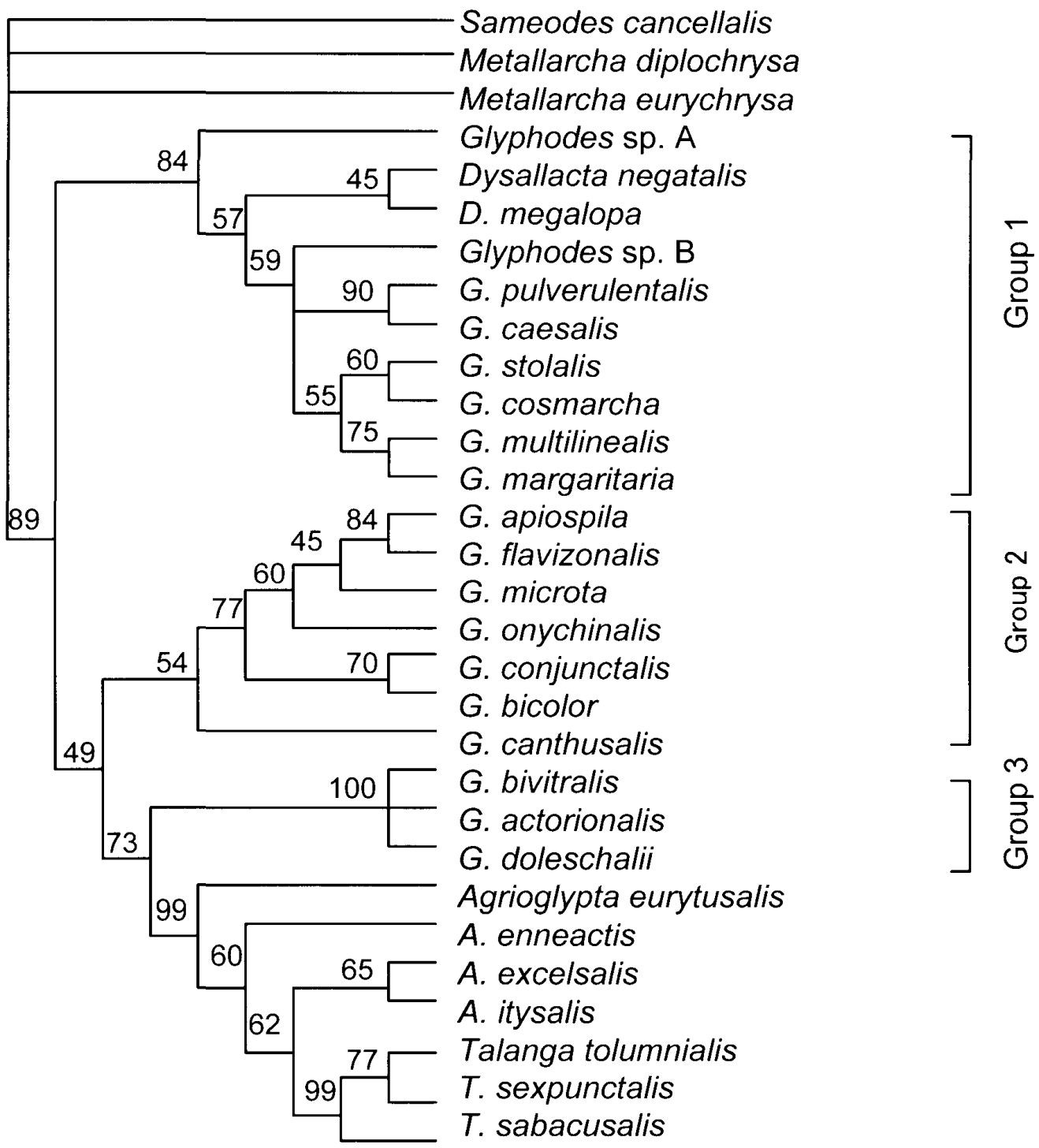

Fig. 1. Strict consensus of 12 equal MP trees based on morphological data (from Sutrisno 2002), showing bootstrap values and division of genus Glyphodes into three monophyletic groups.

monophyletic, but paraphyletic with respect to both the Agrioglypta+Talanga clade and Dysallacta. Groups 2 and 3 of Glyphodes formed a clade with Agrioglypta + Talanga, not with Group 1 of Glyphodes. Dysallacta was nested within Group 1 of Glyphodes, making this group paraphyletic as well. The reliability of each grouping was supported only by low bootstrap values.

\section{DNA sequencing}

A total of 24 adult moths (23 species of the four genera Glyphodes, Talanga, Agrioglypta, and Metallarcha) were collected from eight localities in Indonesia and Australia (Table 1) by using a light trap and preserved in $99.5 \%$ ethanol. No specimens of Dysallacta were collected, and, therefore, this genus was not included in the present study. DNA was extracted from the thorax of each individual. The tis- 
Table 1. Moth species from Indonesia and Australia used for the present study.

\begin{tabular}{|c|c|c|}
\hline Species & Locality & Date \\
\hline \multicolumn{3}{|l|}{ Agrioglypta } \\
\hline eurytusalis (Walker, 1859) & G. Pangrango NP & Sep. 2000 \\
\hline excelsalis (Walker, 1866) & Bucasia, Queensland & Apr. 2001 \\
\hline itysalis (Walker, 1859) & Halimun NP, Java & Mar. 2002 \\
\hline naralis (Felder and Rogenhofer, 1875) & Halimun NP, Java & Mar. 2002 \\
\hline \multicolumn{3}{|l|}{ Glyphodes } \\
\hline actorionalis (Walker, 1859) & Sorong, Papua & Feb. 2002 \\
\hline apiospila (Turner, 1922) & Sorong, Papua & Feb. 2002 \\
\hline bicolor (Swainson, 1821) & Sorong, Papua & Feb. 2002 \\
\hline bivitralis Guenée, 1854 & Patinuang, Sulawesi & Apr. 2001 \\
\hline caesalis (Walker, 1866) & Manado, Sulawesi & Mar. 2001 \\
\hline conjunctalis Walker, 1866 & Sorong, Papua & Feb. 2002 \\
\hline cosmarcha Meyrick, 1887 & Patinuang, Sulawesi & Apr. 2001 \\
\hline doleschalii Lederer, 1863 & Sorong, Papua & Jan. 2002 \\
\hline flavizonalis Hampson, 1898 & Sorong, Papua & Jan. 2002 \\
\hline margaritaria (Clerck, 1754) 1 & Patinuang, Sulawesi & Apr. 2001 \\
\hline margaritaria (Clerck, 1754) 2 & Patinuang, Sulawesi & Apr. 2001 \\
\hline multilinealis Kenrick, 1907 & Bantimurung, Sulawesi & Apr. 2001 \\
\hline onychinalis (Guenée, 1854) & Bucasia, Queensland & Apr. 2001 \\
\hline pulverulentalis Hampson, 1896 & Sukabumi, Java & Feb. 2002 \\
\hline pseudocaesalis Rotshchild, 1915 & Sorong, Papua & Feb. 2002 \\
\hline stolalis Guenée, 1854 & Halimun NP, Java & Mar. 2002 \\
\hline \multicolumn{3}{|l|}{ Metallarcha } \\
\hline aureodiscalis (Hampson, 1918) & Bucasia, Queensland & Apr. 2001 \\
\hline \multicolumn{3}{|l|}{ Talanga } \\
\hline sabacusalis (Walker, 1859) & Patinuang, Sulawesi & Apr. 2001 \\
\hline sexpunctalis Moore, 1885 & Patinuang, Sulawesi & Apr. 2001 \\
\hline tolumnialis (Walker, 1859) & Bucasia, Queensland & Apr. 2001 \\
\hline
\end{tabular}

sue was homogenized in a $1.5 \mathrm{ml}$ microcentrifuge tube containing $600 \mu \mathrm{l}$ of CTAB buffer with $4 \%$ polyvinyl pyrrolidone, and incubated at $55^{\circ} \mathrm{C}$ for two hours. The solution was extracted using phenol saturated with TE buffer $(10 \mathrm{mM}$ Tris-HCL, pH 8.0, $1 \mathrm{mM}$ EDTA), then washed once with one volume of phenol:chloroform: isoamyl alcohol (25:24:1) and twice with chloroform: iso-amyl alcohol. The aqueous phase was transferred to a new tube and then 1.5 volumes of isopropanol were added to precipitate the DNA. This tube was then left at $-20^{\circ} \mathrm{C}$ for more than one hour. The DNA precipitant was pelleted by centrifugation at $13,000 \mathrm{rpm}$ for $20 \mathrm{~min}$, then washed with $70 \%$ ethanol, air dried, and re-dissolved in $50 \mu \mathrm{l}$ of TE buffer.

For PCR amplification and DNA sequencing we used Mt D-4 and Mt D-9 primers (http://www.biotech.ubc.ca) to amplify the COI gene for a total of $686 \mathrm{bp}$, and A-tLEU and B-tLYS primers (Liu and Beckenbach 1992) to amplify the COII gene for a total of $687 \mathrm{bp}$. The complete sequences of the primers used were Mt D-4: 5'-TACA ATTTATCGCCTAAACTTCAG CC-3', Mt D-9: 5'-CCCGGTAAAATTAAA ATATA AACTTC-3', A-tLEU: 5' - ATGGCAGATTAGTGCAATGG-3', and B-tLYS: 5'GTTTA AGAGACCAGTACTTG-3'. The amplification of COI and COII was conducted as follows: one cycle of denaturation at $94^{\circ} \mathrm{C}$ for $10 \mathrm{~min}$, followed by $30 \mathrm{cy}$ cles each consisting of $30 \mathrm{~s}$ of denaturation at $94^{\circ} \mathrm{C}, 60 \mathrm{~s}$ of annealing at $47^{\circ} \mathrm{C}$, and 
$120 \mathrm{~s}$ of extension at $72^{\circ} \mathrm{C}$.

For amplifying $973 \mathrm{bp}$ of the EF-1 $\alpha$ gene, we used two pairs of primers, EF 44: 5'-GCYGARCGYARCGTGGTATYAC-3' (2277) and EF Mid: 5'-CA ATACCRCCRA TTTTGT-3' (2717) for $493 \mathrm{bp}$ and EF M51.9: 5'-CARGACGTATAC AAAATCGG-3' (2832) and EF rcM44: 5'-ACAGCVACKGTYTGYCTCATRTC-3' (3344) for 480 bp (Cho et al. 1995). Numbers in brackets at the 3 '-end of each primer refer to nucleotide positions in the Drosophila melanogaster DNA sequence (Cho et al. 1995). All PCR reactions were performed in a $50 \mu \mathrm{l}$ volume containing $5 \mathrm{pM}$ of each primer, $2 \mathrm{mM}$ dNTPs, $2.5 \mathrm{mM} \mathrm{MgCl}_{2}, 1 \times$ buffer, and $0.25 \mathrm{U}$ of Taq polymerase, using a Takara Thermal Cycler MP (Takara) with the following PCR protocol: one cycle of denaturation at $94^{\circ} \mathrm{C}$ for $10 \mathrm{~min}$, followed by 35 cycles each consisting of denaturation at $92^{\circ} \mathrm{C}$ for $30 \mathrm{~s}$, annealing at $47^{\circ} \mathrm{C}$ for $30 \mathrm{~s}$, and extension at $72^{\circ} \mathrm{C}$ for $1 \mathrm{~min} 30 \mathrm{~s}$. These cycles were completed by final extension at $72^{\circ} \mathrm{C}$ for $10 \mathrm{~min}$ and the PCR products were purified using the QIAquick PCR Purification Kit (Qiagen, USA).

Cycle sequencing was done using 35 cycles of denaturation at $96^{\circ} \mathrm{C}$ for $10 \mathrm{~min}$, annealing at $50^{\circ} \mathrm{C}$ for $5 \mathrm{~min}$, and extension at $60^{\circ} \mathrm{C}$ for $4 \mathrm{~min}$; thereafter, the products were purified using phenol-chloroform. Sequencing of the purified PCR product was performed using ABI PRISM Dye Terminator Cycle Sequencing Ready Reaction Kits (Perkin-Elmer) on an ABI PRISM model 310 Genetic Analyzer (PE Applied Biosystems). The sequences were aligned using BioEdit Sequence Alignment Editor (Hall 1999).

The remaining parts of the specimens used for the present study were deposited at the Museum Zoologicum Bogoriense, Bogor, Indonesia.

\section{Substitutions and transition/transversion ratio}

Transitional and transversional substitutions and the transition/transversion ratio were calculated using the DSET option in PAUP 4.0b4a (Swofford 2001) and then were transferred into Microsoft Excel for plotting on graphs.

\section{Phylogenetic analysis}

In the phylogenetic analysis with PAUP 4.0b4a (Swofford 2001), we adopted the Maximum-Parsimony (MP) method with heuristic searches using the TBR branchswapping option and 1000 random addition sequences (Swofford and Olsen 1990), and statistical confidence was evaluated by bootstrapping tests with 1000 replications (Felsenstein 1985).

Metallarcha aureodiscalis (Hampson, 1918) was used as an outgroup in the present analysis because Metallarcha is closely-related to Glyphodes and its allied genera (Sutrisno 2002). As another outgroup, Ostrinia nubilalis Hübner, 1825 (Pyralidae) was used beacuse sequences of its COI-COII and EF-1 $\alpha$ genes were available from GenBank (accession numbers U60990 and AF 173390, respectively).

\section{Results}

\section{Base composition}

Sequences of 22 species of Glyphodes, Talanga, and Agrioglypta, as well as those of the outgroup species, Metallarcha aureodiscalis, were aligned with no evidence of insertion or deletion. The sequences of all 23 species have been submitted 
Table 2. Percentages of variable and informative sites of COI, COII, and EF-1 $\alpha$, with the number of positions in parentheses.

\begin{tabular}{cccc}
\hline & \multicolumn{1}{c}{ COI } & COII & EF-1 $\alpha$ \\
\hline Total positions & 686 & 687 & 973 \\
Variable (each codon position) & $36.1(248 / 686)$ & $32.3(222 / 687)$ & $24.5(239 / 973)$ \\
First codon position & $21.3(49 / 229)$ & $18.7(43 / 229)$ & $6.4(21 / 325)$ \\
Second codon position & $8.7(20 / 229)$ & $6.5(15 / 229)$ & $4.9(16 / 324)$ \\
Third codon position & $78.5(179 / 228)$ & $67.2(154 / 229)$ & $62.2(202 / 324)$ \\
Informative (each codon position) & $22.7(156 / 686)$ & $19.9(137 / 687)$ & $16.1(157 / 973)$ \\
First codon position & $10.9(25 / 229)$ & $12.2(28 / 229)$ & $3.4(11 / 325)$ \\
Second codon position & $1.3(3 / 229)$ & $3.5(8 / 229)$ & $0.9(3 / 324)$ \\
Third codon position & $56.14(128 / 228)$ & $44.1(101 / 229)$ & $44.1(143 / 324)$ \\
\hline
\end{tabular}

Table 3. Base composition of COI, COII, and EF-1 $\alpha$.

\begin{tabular}{lccccc}
\hline & \multicolumn{3}{c}{ Codon position } & Mean & SD \\
\cline { 2 - 3 } & First & Second & Third & & \\
\hline & & COI & & & \\
A & 0.315 & 0.170 & 0.479 & 0.322 & 0.009 \\
C & 0.140 & 0.266 & 0.277 & 0.145 & 0.006 \\
G & 0.266 & 0.169 & 0.011 & 0.149 & 0.002 \\
T & 0.277 & 0.411 & 0.460 & 0.382 & 0.01 \\
Bias $(C)$ & & & & 0.273 & \\
A & 0.376 & COII & & & \\
C & 0.140 & 0.166 & 0.415 & 0.362 & 0.006 \\
G & 0.183 & 0.127 & 0.034 & 0.112 & 0.006 \\
T & 0.298 & 0.41 & 0.537 & 0.107 & 0.004 \\
Bias $(C)$ & & & & 0.416 & 0.008 \\
& & EF-1 $\alpha$ & & & \\
A & 0.282 & 0.321 & 0.134 & 0.253 & 0.004 \\
C & 0.184 & 0.268 & 0.439 & 0.298 & 0.004 \\
G & 0.380 & 0.141 & 0.206 & 0.243 & 0.002 \\
T & 0.151 & 0.268 & 0.219 & 0.212 & 0.003 \\
Bias $(C)$ & & & & 0.064 & \\
\hline
\end{tabular}

to the DNA Data Bank of Japan (http://www.ddbj.nig.ac.jp) under the accession numbers AB158228-158251, AB158321-158344, and AB158377-158400.

As shown in Table 2, the proportion of informative sites varied among genes, constituting $22.7 \%$ of $686 \mathrm{bp}$ for COI, $19.9 \%$ of $687 \mathrm{bp}$ for COII, and $16.1 \%$ of $973 \mathrm{bp}$ for EF-1 $\alpha$. The third-codon positions were most variable, and the second-codon positions least variable, in all genes. The proportion of informative sites in the first, second, and third positions of a codon were $3.4-12.2 \%, 0.9-3.5 \%$, and $44.1-56.14 \%$, respectively.

Fig. 2 shows the relationships between un-corrected pairwise distances for transitions (Ts) and those for transversions (Tv) at the third codon position. In COI and EF-1 $\alpha$, Ts almost linearly increased with respect to Tv and exceeded $\mathrm{Tv}$ in all 

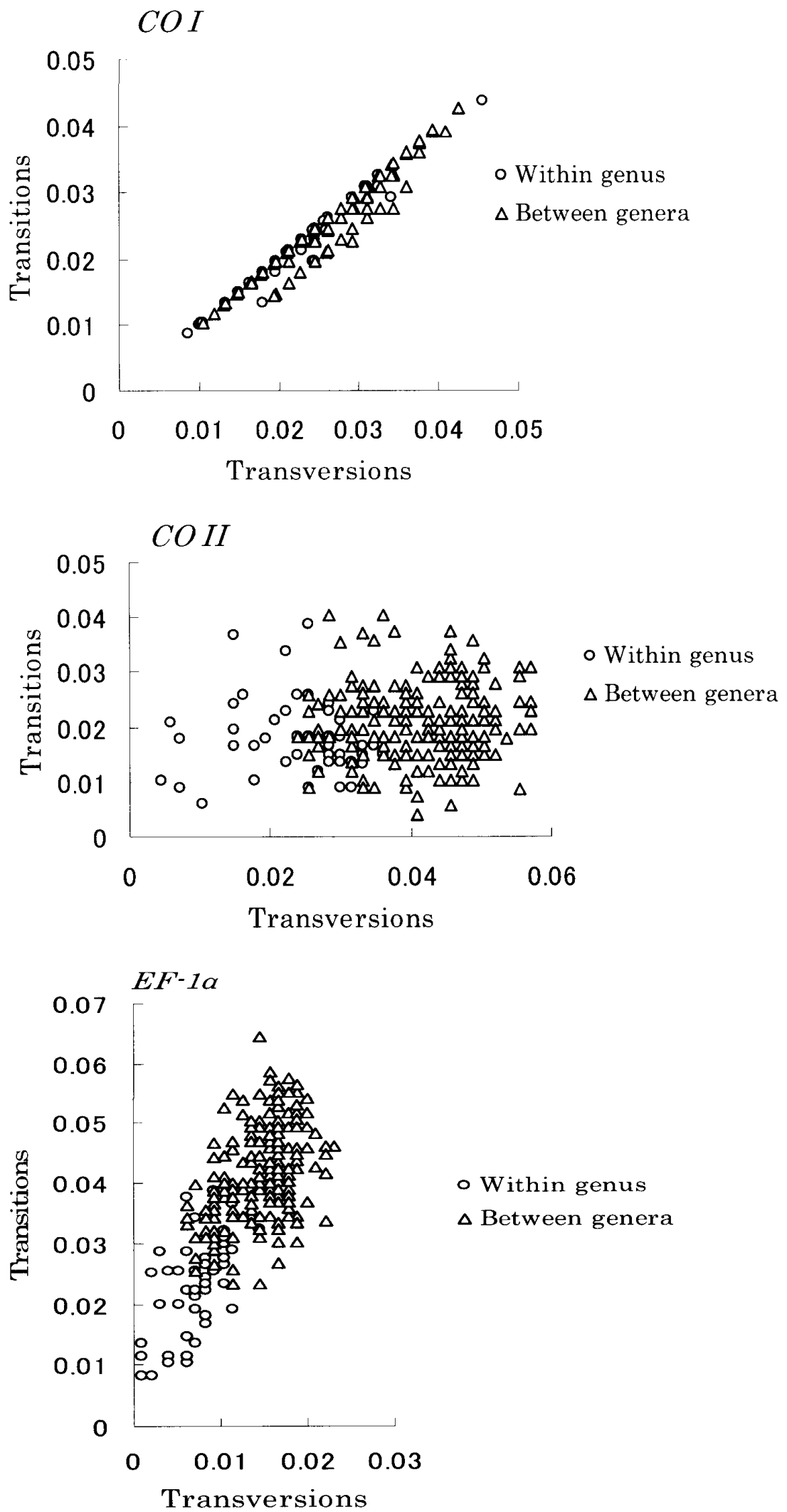

○ Within genus

$\Delta$ Between genera

Fig. 2. Transitions (Ts) versus transversions (Tv) of third codon positions in COI, COII, and EF-1 $\alpha$. 


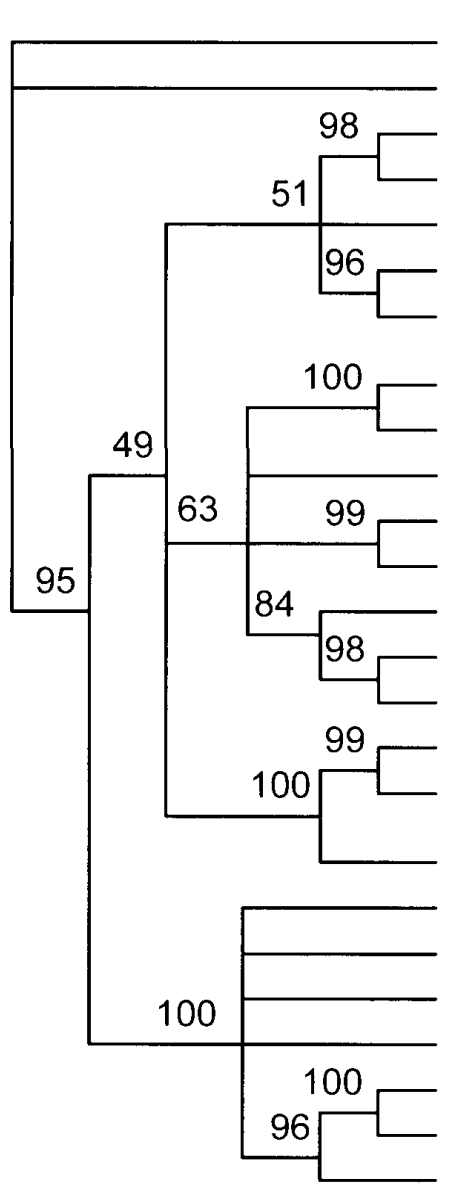

Ostrinia nubilalis Metallarcha aureodiscalis Glyphodes apiospila G. flavizonalis G. onychinalis G. conjunctalis G. bicolor G. caesalis G. pseudocaesalis G. pulverulentalis G. margaritaria 1 G. margaritaria 2 G. cosmarcha G. stolalis G. multilinealis $G$. actorionalis G. bivitralis G. doleschalii Agrioglypta naralis A. excelsalis A. itysalis A. eurytusalis Talanga tolumnialis $T$. sexpunctalis T. sabacusalis

Fig. 3. Strict consensus of eight MP trees based on COI and EF- $1 \alpha$, showing bootstrap values and division of genus Glyphodes into three monophyletic groups.

pairwise species comparisons, indicating no saturation of Ts and Tv. The values of linear regressions in $\mathrm{COI}$ and $\mathrm{EF}-1 \alpha$ were $\mathrm{Y}=0.968 \mathrm{x}, \mathrm{R}^{2}=0.951$, and $\mathrm{Y}=2.719 \mathrm{x}, \mathrm{R}^{2}=$ 0.1882 , respectively. In contrast, COII appeared saturated with transitions when compared between genera and its linear regression was $\mathrm{Y}=0.497 \mathrm{x}, \mathrm{R}^{2}=-0.496$.

\section{Phylogeny based on pooled data of COI, COII, and EF-1 $\alpha$}

With all base substitutions in COI and EF-1 $\alpha$ accorded equal weighting, an heuristic search resulted in eight MP trees $(\mathrm{TL}=1264, \mathrm{CI}=0.471, \mathrm{RI}=0.515)$, the strict consensus of which is presented in Fig. 3. The genus Glyphodes appears as a monophyletic group divided into three clades, but the reliability of the relationship among the latter is scarcely supported by the bootstrap values. The genera Agrioglypta and Talanga together form one clade with very strong bootstrap support.

Using all the molecular data of COI, COII, and EF-1 $\alpha$, an heuristic search resulted in two MP trees $(\mathrm{TL}=1880, \mathrm{CI}=0.4649, \mathrm{RI}=0.502)$, the consensus of which is presented in Fig. 4. These two trees differ in the position of Glyphodes group 2. In one tree, this group branches off first, followed by the Agrioglypta + Talanga clade, while in the other tree, the Agrioglypta + Talanga clade occupies the basal node. In 


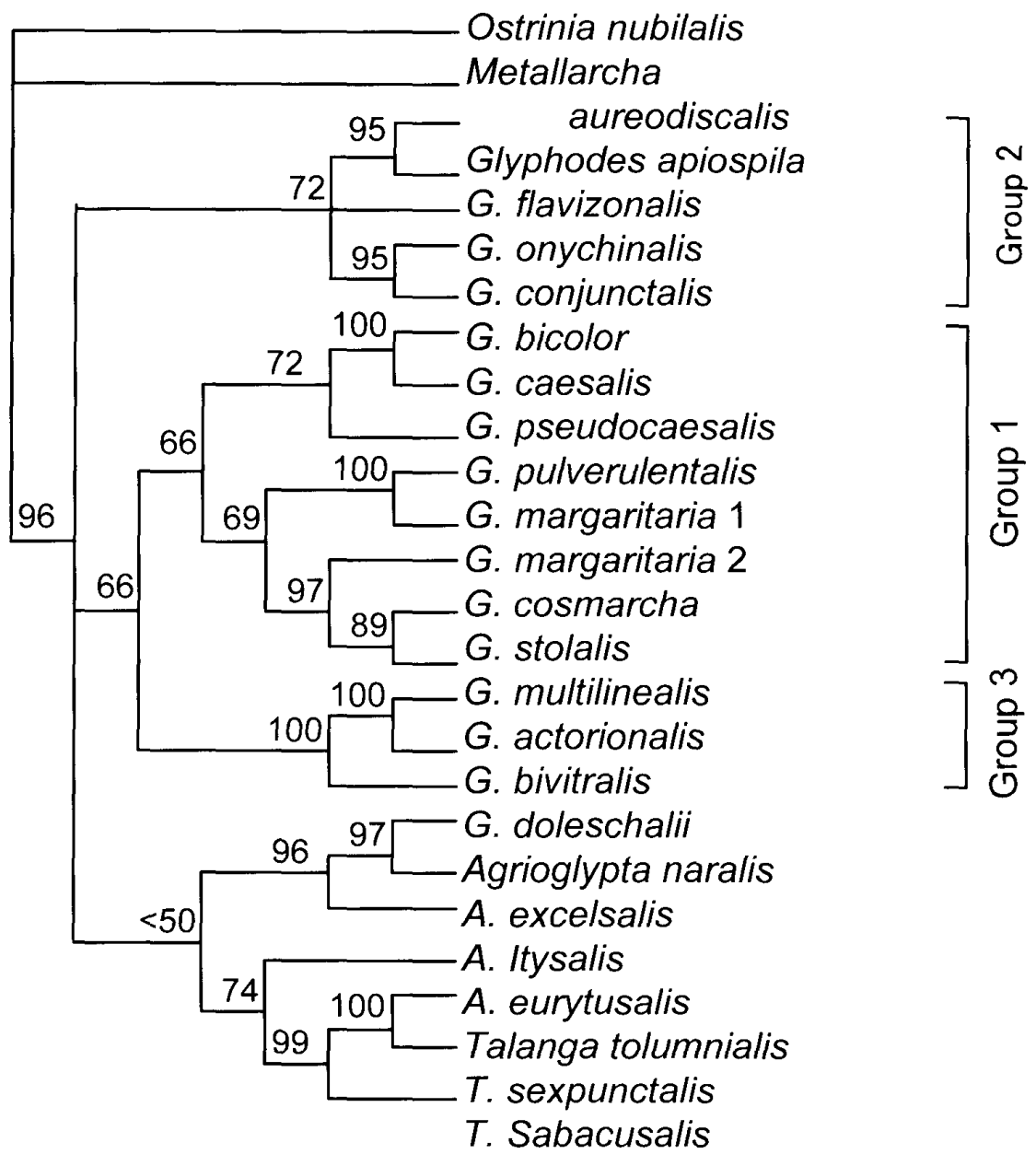

Fig. 4. Strict consensus of two MP trees based on COI, COII, and EF-1 $\alpha$, showing bootstrap values and division of genus Glyphodes into three monophyletic groups.

both trees the genus Glyphodes is divided into three clades and the genus Agrioglypta is not monophyletic, since A. eurytusalis (Walker, 1859) falls out with the genus Talanga, occupying the basal node of this latter genus.

\section{Phylogeny based on a combination of molecular and morphological data}

Another phylogenetic analysis was conducted using all substitutions in COI, COII, and EF-1 $\alpha$ as well as 40 morphological characters from Sutrisno (2002). An heuristic search discovered a single MP tree ( $\mathrm{TL}=2014, \mathrm{CI}=0.478, \mathrm{RI}=0.541$ ) (Fig. 5). The topology of this tree is very similar to that of the second tree in the previous analysis based on molecular data (compare Figs 4 and 5). The three Glyphodes groups were again recognized, with Group 2 branching off first, followed by Groups 3 and 1 . However, the monophyly of this genus was only supported by a low bootstrap value $(<50 \%)$. The best support was found for the monophyly of Group 3 $(100 \%)$. 


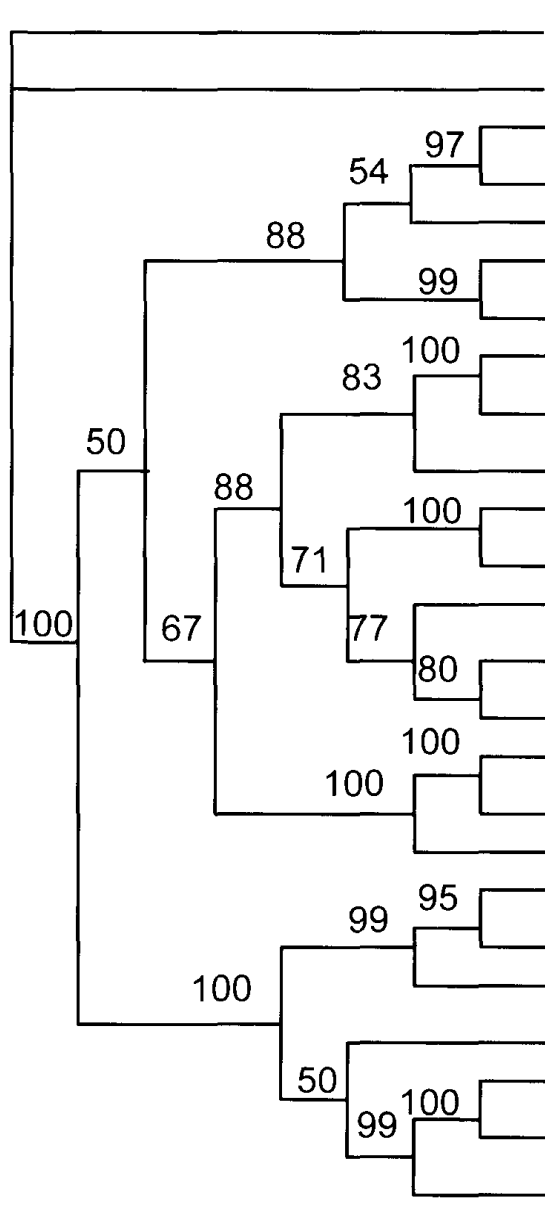

Ostrinia nubilalis Metallarcha aureodiscalis Glyphodes apiospila G. flavizonalis

G. onychinalis

G. conjunctalis

G. bicolor

G. caesalis

G. pseudocaesalis

G. pulverulentalis

G. margaritaria 1

G. margaritaria 2

G. cosmarcha

G. stolalis

G. multilinealis

G. actorionalis

G. bivitralis

G. doleschalii

Agrioglypta naralis

A. excelsalis

A. Itysalis

A. eurytusalis

Talanga tolumnialis

T. sexpunctalis

T. Sabacusalis

Fig. 5. MP tree based on a combination of molecular and morphological data, showing bootstrap values and division of genus Glyphodes into three monophyletic groups.

\section{Discussion}

In insect genomes, the base composition is generally A+T-biased in mitochondrial genes but not in nuclear genes (Clary and Wolstenholme 1985; DeSalle et al. 1987; Goto and Kimura 2001). The present study also revealed an A+T bias in COI $(70.6 \%)$ and COII $(77.8 \%)$, but not in EF-1 $\alpha(46.5 \%)$. In COI and COII, the highest bias is observed at the third-base position. In general, A+T-rich compositions show a higher substitution rate than $\mathrm{G}+\mathrm{C}$-rich or non-biased compositions (Moriyama and Powell 1997).

Transitions occur more frequently than Transversions, and Ts values are usually expected to exceed Tv values (DeSalle et al. 1987; Kondo et al. 1993); however, it has been reported for some mitochondrial DNA that Tv values exceed Ts values (Xiong and Kocher 1993; Simon et al. 1994; Goto and Kimura 2001). This is primarily because transversions erase the record of transitions after genes are saturated with the latter (Irwin et al. 1991; Beckenbach et al. 1993; Simon et al. 1994). The substitutions at the third codon position of COII revealed in the present study also show Tv values that exceed Ts ones when sequences are compared between distantly-related species (Fig. 2). By contrast, the COI and EF-1 $\alpha$ genes (more conser- 
vative genes) show Ts values that exceed the Tv ones, which indicates that these genes were not yet saturated with transitions. As a result of this phenomenon, the $\mathrm{COI}$ and EF- $1 \alpha$ genes contribute to resolving the relationships at basal nodes whereas COII contributes to resolving the relationships among closely-related species (Figs 3,4). These results are quite similar to those found in a study of the tribe Attacini (Saturnidae), in which EF-1 $\alpha$ serves well to resolve relationships among genera but is often poor in resolving phylogeny within a genus (Friedlander et al. 1998).

The most significant difference between the topologies based on molecular and morphological data concerns the relationships among the groups within the genus Glyphodes and also within the clade formed by Glyphodes Group 3, Agrioglypta, and Talanga. In the earlier morphological analysis, Sutrisno (2002) failed to find any single good character to support the monophyly of Glyphodes. As a result, the genus Glyphodes could not be shown to be monophyletic. In addition, the morphological characters that had been regarded by Sutrisno (2002) as synapomorphies to support the monophyly of Glyphodes Group 3+Agrioglypta+Talanga, such as a narrow bulbus ejaculatorious, a bulbus ejaculatorius much longer than the aedeagus, a ductus bursae five times longer than the longitudinal diameter of the corpus bursae, and a funnel-shaped thin membrane in the posterior part of the ductus bursae (from ostium to antrum), are homoplasious characters. These characters evolved independently in Glyphodes group 3, Agrioglypta, Talanga, and Achyra nudalis Hübner, 1825 (Pyraustinae) (Maes 1995; Sutrisno 2002). This suggests that the clade based on the above morphological characters is not a monophyletic group. Sutrisno's (2002) morphological analysis failed to resolve relationships among species within Glyphodes Group 3 because the characters of the male genitalia of this group were difficult to score informatively. Still, there were enough morphological synapormophies to support the monophyly of this clade, such as the well developed, brush-like extension at the distal end of the male patagia, the large, globose head of the uncus with a series of thorn-like spines at the apex, and the rounded to ovate signum with pointed denticles (Sutrisno 2002).

The combination of morphological and molecular data presented here shows more clearly the relationships among Glyphodes, Agrioglypta, and Talanga. Glyphodes comprises three distinct clades. The best support for monophyly was found for Group 3, and the relationships among the species in this group are very clear: G. bivitralis Guenee, 1854 is the sister species of G. actorionalis Walker, 1859, and $G$. doleschalli Lederer, 1863 occupies its basal node. Agrioglypta consistently appears to be a paraphyletic group, forming a clade together with Talanga and occupying that clade's basal node. Agrioglypta is thus not a valid genus.

The combination of morphological and molecular data in the present study suggests that the genus Glyphodes is monophyletic. Each group of Glyphodes, especially Group 3, might conceivably be raised to the generic level. The position of the genus Dysallacta is still unclear, since there is no available material for molecular studies. Further studies including all species of the four genera are still needed to test the present hypothesis. 


\section{Acknowledgments}

Our grateful thanks are owed to Dr M. Horak (CSIRO) for her generous support at the beginning of this study and her kind provision of voucher specimens, and Ken J. Sandery for collecting and sending the specimens from Australia. We also thank M. Rofik, E. Cholik, and Darmawan (Museum Zoologicum Bogoriense) for their assistance in collecting specimens at Halimun National Park and $\mathrm{Mr} \mathrm{H}$. Sato for his technical support especially in sequencing. This study was partly funded by the Ministry of Education, Science, Sports and Culture of Japan.

\section{References}

Beckenbach, A. T., Wei, Y. W. and Liu, H. 1993. Relationships in the Drosophila obscura species group, inferred from mitochondrial cytochrome oxidase II sequences. Molecular Biology and Evolution 10: 619-634.

Blum, J. M., Bermingham, E. and Dasmahapatra, K. 2003. A molecular phylogeny of the neotropical butterflies genus Anartia (Lepidoptera: Nymphalidae). Molecular Phylogenetics and Evolution 26: 46-55.

Brower, A. V. Z. 1994. Phylogeny of Heliconius butterflies inferred from mitochondrial DNA sequences (Lepidoptera: Nymphalidae). Molecular Phylogenetics and Evolution 3: 159 174.

Brower, A. V. Z. and DeSalle, R. 1998. Patterns of mitochondrial versus nuclear DNA sequences divergence among nymphalid butterflies: the utility of wingless as a source of characters for phylogenetic inference. Insect Molecular Biology 7: 73-82.

Caterino, M. S., Cho, S. and Sperling, F. A. H. 2000. The current state of insect molecular systematics: a thriving Tower of Babel. Annual Review of Entomology 45: 1-54.

Caterino, M. S., Reed, R. D., Kuo, M. M. and Sperling, F. A. H. 2001. A portioned likelihood analysis of swallowtail butterfly phylogeny (Lepidoptera: Papilionidae). Systematic Biology 50: 106-127.

Caterino, M. S. and Sperling, F. A. 1999. Papilio phylogeny based on mitochondrial cytochrome oxidase I and II genes. Molecular Phylogenetics and Evolution 11: 122-137.

Cho, S., Mitchel, A., Regier, J. C., Mitter, C., Poole, R., Friedlander, T. P. and Zhao, S. 1995. A highly conserved nuclear gene for low-level phylogenetics: elongation factor- $1 \alpha$ recovers morphology-based tree for heliothine moths. Molecular Biology and Evolution 12: 650656.

Clary, D. O. and Wolstenholme, D. R. 1995. The mitochondrial DNA molecule of Drosophila yakuba: nucleotide sequence, gene organization, and genetic code. Journal of Molecular Evolution 22: 252-271.

Common, I. F. C. 1990. Moths of Australia. Melbourne University Press, Carlton, 535 pp.

DeSalle, R., Freedman, T., Prager, E. M. and Wislon, A. C. 1987. Tempo and mode of sequence evolution in mitochondrial DNA of Hawaiian Drosophila. Journal of Molecular Evolution 26: 157-164.

Felsenstein, J. 1985. Confidence limits on phylogenies: an approach using the bootstrap. Evolution 39: 783-791.

Friedlander, T. P., Horst, K. R., Regier, J. C., Mitter, C., Peigler, R. S. and Fang, Q. Q. 1998. Two nuclear genes yield concordant relationship within Attacini (Lepidoptera: Saturnidae). Molecular Phylogenetics and Evolution 9: 131-140.

Goto, S. G. and Kitamura, M. T. 2001. Phylogenetic utility of mitochondrial CO I and nuclear 
Gdph genes in Drosophila. Molecular Phylogenetics and Evolution 18: 404-422.

Goto, S. G., Kitamura, W. H. and Kimura, M. T. 2000. Phylogenetic relationships and climatic adaptations Drosophila takahashii and montium species subgroups. Molecular Phylogenetics and Evolution 15: 147-156.

Hall, T. A. 1999. BioEdit: a user-friendly biological sequence alignment editor and analysis program for windows 95/98/NT. Nucleic Acid Symposium Series 41: 95-98.

Irwin, D. M., Kocher, T. D. and Wilson, A. C. 1991. Evolution of the cytochrome b gene of mammals. Journal of Molecular Evolution 32: 128-144.

Kalshoven, L. G. E. 1981. Pest of Crops in Indonesia. PT. Ichtiar Baru-Van Hoeve, Jakarta, 701 pp.

Kondo, R., Horai, S., Satta, Y. and Takahata, N. 1993. Evolution of hominoid mitochondrial DNA with special reference to the silent substitution rate over the genome. Journal of Molecular Evolution 36: 517-531.

Kuroko, H. and Lewvanich, A. 1993. Lepidopterous Pests of Tropical Trees in Thailand (with Thai Text). Japan International Cooperation Agency, Tokyo, $132 \mathrm{pp}$.

Liu, H. and Beckenbach, A. T. 1992. Evolution of the mitochondrial cytochrome oxidase II gene among 10 orders of insects. Molecular Phylogenetics and Evolution 1: 41-52.

Maes, K. V. N. 1995. A comparative morphological study of the adult Crambidae (Lepidoptera: Pyraloidea). Bulletin \& Annales de la Société Royale Belge d'Entomologie 13: 265 434.

Monteiro, A. and Pierce, N. E. 2001. Phylogeny of Bicyclus (Lepidotera: Nymphalidae) inferred from COI, COII and EF-1 $\alpha$ gene sequences. Molecular Phylogenetics and Evolution 18: $264-281$.

Moriyama, E. N. and Powell, J. R. 1997. Synonymous substitution rates in Drosophila: mitochondrial versus nuclear genes. Journal of Molecular Evolution 45: 378-391.

Robinson, G. S., Tuck, K. R. and Shaffer, M. 1994. Field Guide to the Smaller Moths of South East Asia. Malaysian Nature Society, Kuala Lumpur, $296 \mathrm{pp}$.

Rubinoff, D. and Sperling, F. A. H. 2002. Evolution of ecological traits and wing morphology in Hemileuca (Saturniidae) based on a two-gene phylogeny. Molecular Phylogenetics and Evolution 25: 70-86.

Shaffer, M. A., Nielsen, E. S. and Horak, M. 1996. Pyraloidea. Pp. 164-199. In: Nielsen, E. S., Edwards, E. S. and Rangsi, T. V. (Eds) Checklist of the Lepidoptera of Australia. CSIRO Publishing, Collingwood, Australia.

Simon, C., Frati, F., Beckenbach, A. T., Crespi, B., Liu, H. and Flook, P. 1994. Evolution, weighting, and phylogenetic utility of mitochondrial gene sequences and a compilation of conserved polymerase chain reaction primers. Annals of the Entomological Society of America 87: 651-701.

Sperling, F. A. H. and Hickey, D. A. 1994. Mitochondrial DNA sequences variation in the spruce budworm species complex (Choristoneura: Lepidoptera). Molecular Biology and Evolution 1: 656-665.

Sutrisno, H. 2002. Cladistic analysis of the Australian Glyphodes Guenée and allied genera (Lepidoptera: Crambidae; Spilomelinae). Entomological Science 5: 457-467.

Swofford, D. L. 2001. PAUP*. Phylogenetic Analysis Using Parsimony (and Other Methods). Version 4.0b10 for 32-bit Microsoft Windows. Sinauer Associates, Sunderland, Massachusetts.

Swofford, D. L. and Olsen, G. J. 1990. Phylogeny reconstruction. Pp. 411-501. In: Hills, D. M. and Moritz, C. (Eds) Molecular Systematics. Sinauer Associates, Sunderland, Massachusetts.

Xiong, B. and Kocher, T. D. 1993. Intraspecific variation in sibling species of Simulium venustum and $S$. verecundum complexes (Diptera: Simuliidae) revealed by the sequences of the mitochondrial 16S rRNA gene. Canadian Journal of Zoology 71: 1202-1206. 